DOI: https://doi.org/10.24127/ajpm.v8i3.2203

\title{
PENGARUH PROJECT BASED LEARNING BERBASIS MEDIA INTERAKTIF TERHADAP KEMAMPUAN KOMUNIKASI MATEMATIS
}

\author{
Restu Lusiana ${ }^{1}$, Vera Dewi Susanti ${ }^{2}$, Tri Andari ${ }^{3}$ \\ ${ }^{1,2,3}$ Pendidikan Matematika, Universitas PGRI Madiun \\ E-mail: $\quad$ restu.mathedu@unipma.ac.id ${ }^{l)}$ \\ vera.mathedu@unipma.ac.id $\left.{ }^{2}\right)$ \\ triandari.mathedu@unipma.ac.id ${ }^{3)}$
}

Received 19 August 2019; Received in revised form 30 November 2019; Accepted 24 December 2019

\begin{abstract}
Abstrak
Penelitian ini bertujuan untuk melihat pengaruh project based learning berbasis media interaktif terhadap kemampuan komunikasi matematis mahasiswa pada materi garis singgung lingkaran. Subjek dalam penelitian ini adalah mahasiswa program studi pendidikan matematika Universitas PGRI Madiun. Jenis penelitian ini adalah studi korelasional untuk melihat hubungan antara project based learning berbasis media interaktif terhadap kemampuan komunikasi matematis mahasiswa. Populasi dalam penelitian ini berjumlah 58 siswa, dan sampel menggunakan semua populasi. Penelitian ini menggunakan instrumen tes prestasi belajar dan tes kemampuan komunikasi matematis. Analisis data yang digunakan dalam penelitian ini adalah analisis regresi sederhana dengan rumus koefisien korelasi product moment. Hasil penelitian menunjukkan bahwa project based learning berbasis media interaktif memiliki korelasi positif terhadap kemampuan komunikasi matematis mahasiswa sebesar $77 \%$. Ini menunjukkan bahwa selain project based learning berbasis media interaktif, masih ada $23 \%$ dari faktor lain yang memiliki efek positif pada keterampilan komunikasi matematika siswa.
\end{abstract}

Kata kunci: Komunikasi matematis; media interaktif; project based learning.

\begin{abstract}
This study aims to see the effect of project-based learning using interactive media on students' mathematical communication skills in tangent circles. The subjects in this study were students of mathematics education study program at PGRI Madiun University. This type of research is a correlational study to see the relationship between project-based learning using interactive media on students' mathematical communication skills. The population in this study amounted to 58 students, and the sample used all populations. This study uses a learning achievement test instrument and a mathematical communication ability test. Analysis of the data used in this study is a simple regression analysis with the product moment correlation coefficient formula. The results showed that project-based learning using interactive media had a positive correlation with students' mathematical communication skills by $77 \%$. This shows that besides project-based learning using interactive media, there are still $23 \%$ of other factors that have a positive effect on students' mathematical communication skills.
\end{abstract}

Keywords: Interactive media; mathematical communication; project based learning.

\section{PENDAHULUAN}

Kemampuan matematis merupakan kemampuan seseorang dalam mengkomunikasikan gagasan matematika dengan menggunakan simbol, gambar, tabel, diagram, atau media lain untuk mendeskripsikan suatu masalah (Putri, Dwijayanto, \& Sugiman, 2017).
Kemampuan komunikasi matematis dapat diamati secara lanhgsung maupun tidak langsung (Lisa, Hayati, Djatmika, \& Rahman, 2018). Indikator untuk mengukur kemampuan komunikasi matematis diantaranya adalah menggambarkan, menginterpretasikan, dan mengevaluasi ide matematis, (Lestari \& Yudhanegara, 2015). 
Materi persamaan garis singgung lingkaran merupakan salah satu materi yang dipelajari pada mata kuliah Kajian Matematika Lanjut mahasiswa program studi pendidikan matematika Universitas PGRI Madiun. Berdasarkan hasil evaluasi pada semester sebelumnya didapatkan informasi bahwa, hasil belajar mahasiswa pada materi tersebut belum optimal, hal ini terlihat dari mahasiswa yang mendapat nilai > 65 adalah 34,48\%. Dan berdasarkan hasil tes dan wawancara kemampuan komunikasi matematis, 25 dari 58 mahasiswa masih memiliki kemampuan komunikasi matematis yang rendah.

Rendahnya kemampuan komunikasi matematis mahasiswa diantaranya terjadi pada aspek kemampuan mejelaskan ide, menjelaskan situasi matematis tertulis dengan gambar dan aljabar, menyatakan suatu permasalahan dalam bahasa simbol matematika, membuat konjektur, menyusun argumen, dan membuat pertanyaan tentang apa yang sudah dipelajari. Hal tersebut dikarenakan mahasiswa belum memahami konsep garis singgung lingkaran secara utuh (Imaniar Ramadhan, 2018). Komunikasi matematis berperan penting pada proses pemecahan masalah (Rahman, Yusof, Kashefi, \& Baharun, 2012).

Penelitian-penelitian sebelumnya yang membahas tentang kemampuan komunikasi matematis diawali oleh melihat pengaruh kemampuan komunikasi matematika dengan model pembelajaran reflektif dengan pendekatan matematika realistik bernuansa keislaman yang menunjukkan adanya pengaruh antara keduanya (Putra, 2016), kemudian (Putra, Widyawati, Asyhari, \& Putra, 2018) melihat pengaruh model advance organizer terhadap keterampilan komunikasi matematika dan hasilnya menunjukkan adanya pengaruh antar keduanya, Dan (Fahrullisa, Putra, \& Supriadi, 2018) melihat pengaruh kemampuan komunikasi matematis dengan model pembelajaran kooperatif Tipe Think Pair Share (TPS) berbantuan pendekatan investigasi. Dari beberapa penelitian tersebut belum ada yang melihan pengaruh antara kemampuan komunikasi matematis dengan model Project Based Learning. (Garnjost \& Lawter, 2019) menyatakan bahwa "of the four learner-focused pedagogies, only project based learning was perceived to have a significant impact on problem solving and knowledge acquisition as compared to lecture". Project-based learning has a positive effect on students' academic achievement (Chen \& Yang, 2019). The contribution of project-based learning to (self) development of learners' general and subject competencies has been widely acknowledged (Lasauskiene \& Rauduvaite, 2015). Project Based Learning merupakan model pembelajaran dimana guru memberikan proyek kepada siswa untuk dilakukan. Proyek yang diberikan kepada siswa berisi tugas-tugas yang kompleks berdasarkan permasalahan sebagai langkah awal dalam mengumpulkan dan mengintegrasikan pengetahuan baru. (Amamou \& Chenitibelcadhi, 2018) menyatakan "Learner to be involved in the analysis of a given project and the search for possible solutions". "For mathematics learning to occur, we believed that students should participate actively in the knowledge construction and be able to take charge of their own learning" (Rahman et al., 2012). Untuk mengoptimalkan aktifitas siswa dalam hal merancang, investigasi, memecahkan masalah, dan membuat 
keputusan, guru dapat memberikan tugas proyek (Mulyadi, 2015).

Adapun langkah-langkah Project

Based Learning adalah Start With the Essential Question, Design a Plan for the Project, Create a Schedule, Monitor the Students and the Progress of the Project, Assess the Outcome, Evaluate the Experience (Nuryadi \& Rahmawati, 2018).

Berdasarkan langkah-langkah diatas tercermin pada setiap tahapan pembelajaran Project Based Learning membutuhkan kemampuan komunikasi yang baik, sehingga penelitian ini dilakukan dengan tujuan untuk melihat pengaruh model Project Based Learning terhadap kemampuan komunikasi matematis mahasiswa.

\section{METODE PENELITIAN}

Penelitian ini merupakan
penelitian kuantitatif termasuk penelitian korelasional, yaitu penelitian yang dimaksudkan untuk mengetahui apakah terdapat hubungan antara dua atau beberapa variabel pada suatu penelitian. Penelitian jenis korelasi digunakan untuk menemukan kemungkinan ada tidaknya hubungan antar dua atau lebih variabel bebas dengan variabel terikat. Apapun variabel konstruk bisa dicari hubungannya dalam penelitian sepanjang didukung teori. Berdasarkan arah hubungan dibedakan hubungan positif dan negatif.

Populasi dalam penelitian ini adalah mahasiswa program studi pendidikan matematika semester 4 tahun akademik 2018/2019. Sampel dalam penelitian ini adalah seluruh populasi yaitu sejumlah 58 mahasiswa. Karena jumlah populasi dalam penelitian ini kurang dari 100 orang yakni 58 orang, maka dapat dikatakan penelitian populasi (Tayeb, Sulhaerah,
\& Ali, 2015). Instrumen yang digunakan dalam penelitian ini adalah tes kemampuan komunikasi matematis lisan dan tertulis. Tes kemampuan komunikasi matematis berisi 10 butir soal. Sebelum instrumen digunakan terlebih dahulu dilakukan uji coba instrumen untuk mengetahui validitas, reliabilitas, taraf kesukaran, dan daya pembedanya. Instrumen dapat digunakan jika nilai validitas, reliabilitas, dan daya pebedanya terpenuhi. Instrumen dikatakan valid jika $r_{x y} \geq r_{\text {tabel }}$ dengan taraf signifikan (a) $5 \%$. Sedangkan soal yang nilai validnya $r_{x y} \leq r_{\text {tabel }}$ tidak dipakai (Hamzah, 2014). Instrumen dikatakan reliabel menurut (Arifin, 2017) apabila angka korelasinya diatas 0.60 dan kurang dari 1, maka instrumen tersebut memiliki korelasi tinggi atau reliabel, sedangkan apabila angka korelasinya di bawah 0.50, maka instrumen tersebut berkorelasi rendah atau tidak reliabel. Tolak ukur untuk menginterpretasikan taraf kesukaran tiap butir soal digunakan kriteria sukar dengan indeks $0.00-0.30$, sedang dengan indeks 0.31 0.70 , dan mudah dengan kriteria 0,71 1,00 (Arikunto, 2015). Soal-soal yang digunakan yaitu soal-soal yang mempunyai indeks kesukaran 0.31 sampai dengan 0.70. Menurut (Arikunto, 2015) butir-butir soal yang baik adalah butir-butir soal yang mempunyai indeks daya pembeda 0,4 sampai dengan 0.7. Penelitian ini menggunakan soal yang memiliki indeks daya pembeda 0.4 sampai dengan 1.0.

Analisis yang digunakan dalam penelitian ini adalah analisis korelasi sederhana untuk melihat hubungan antara variabel bebas dan variabel terikat. Variabel bebas dalam penelitian ini adalah Project Based Learning berbasis media interaktif (X) dan 
variabel terikatnya adalah kemampuan komunikasi matematis (Y). Uji korelasi sederhana dinyatakan dalam formula koefisien korelasi momen produk (product moment). Menurut (Sugiyono, 2018) ada pengaruh antara variabel bebas dan terikat jika $r_{\text {hitung }}>r_{\text {tabel }}$.

Sebelum dilakukan analisis korelasi sederhana terlebih dahulu dilakukan uji prasyarat yaitu uji normalitas, uji linieritas, dan uji multikolineritas. Uji normalitas dilakukan menggunakan metode lilliefors. Sampel dapat dikatakan berasal dari populasi yang berdistribusi normal jika $L_{\text {hitung }} \leq L_{\text {tabel }}$ dengan taraf signifikansi 5\% (Budiyono, 2016). Uji Linieritas dilakukan dengan uji $\mathrm{F}$ untuk mengetahui apakah variabel $X$ dan $Y$ pada penelitian ini memiliki hubungan yang linier sebagai syarat untuk dapat dilakukan analisis regresi. Variabel $X$ dan $Y$ dapat dikatakan linier jika $F_{\text {hitung }}$ $<F_{\text {tabel }}($ Budiyono, 2016).

\section{HASIL PENELITIAN DAN PEMBAHASAN}

Penelitian ini mengambil sampel sejumlah 58 mahasiswa. Adapun data tunggal dari masing-masing variabel disajikan pada Tabel 1.

Tabel 1. Ringkasan Data Kemampuan Komunikasi Matematis

\begin{tabular}{cc}
\hline Uraian & Nilai \\
\hline Mean & 58.966 \\
Median & 60.000 \\
Modus & 80.000 \\
Variansi & 204879.464 \\
Standard deviasi & 452.636 \\
\hline
\end{tabular}

Pada bagian ini akan disajikan rangkuman mengenai hasil penelitian yang telah dilakukan meliputi pengujian instrumen dari masing-masing variabel untuk mengetahui kelayakan instrumen sebelum digunakan, uji prasyarat, dan uji hipotesis penelitian.

Adapun hasil ujicoba instrumen tes kemampuan komunikasi matematis terhadap 20 mahasiswa menunjukkan bahwa dari 10 butir soal, 6 diantaranya masuk dalam kriteria valid. Terhadap 6 butir yang valid diperoleh harga $r_{11}=0.901$ ini berarti instrumen tes kemampuan komunikasi matematis reliabel, sehingga dapat digunakan dalam penelitian. Dari 6 butir soal, semuanya memenuhi indeks kesukaran yang tidak terlalu sukar dan terlalu mudah yaitu terletak pada kriteria $0.30<I K \leq 0.70$ dan mempunyai daya pembeda lebih dari $0.40(D P>$ 0.40 ).

Uji persyaratan yang dilakukan sebelum dilakukan pengujian hipotesis adalah uji normalitas dan uji linearitas. Adapun hasil dari uji prasyarat menunjukkan bahwa data berdistribusi normal dan linier. Adapun ringkasan hasil uji prasyarat disajikan pada Tabel 2 dan 3.

Tabel 2. Ringkasan Hasil Pengujian Normalitas Data

\begin{tabular}{lcccc}
\hline \multicolumn{1}{c}{$\begin{array}{c}\text { Perangkat } \\
\text { tes }\end{array}$} & $\mathbf{N}$ & $\boldsymbol{L}_{\text {hitung }}$ & $\boldsymbol{L}_{\text {tabel }}$ & Simpulan \\
\hline $\begin{array}{l}\text { Kemampuan } \\
\text { komunikasi } \\
\text { matematis }\end{array}$ & 58 & 0.059 & 0.116 & Normal \\
\hline
\end{tabular}

Tabel 3. Ringkasan Hasil Pengujian

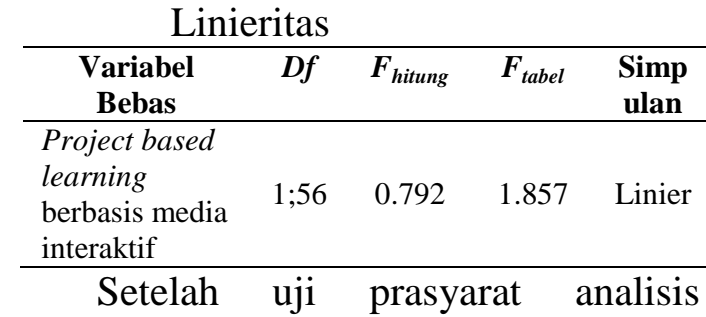
terpenuhi maka dilanjutkan pada pengujian hipotesis. Pengujian hipotesis pada penelitian ini menggunakan Teknik analisis regresi sederhana. Pengolahan terhadap data yang 
DOI: https://doi.org/10.24127/ajpm.v8i3.2203

terkumpul dilakukan dengan analisis data statistik menggunakan bantuan software microsoft excel. Adapun ringkasan hasil analisis regresi linier sederhana dapat dilihat pada Tabel 4.

Tabel 4. Ringkasan Hasil Analisis

\begin{tabular}{ccccc}
\multicolumn{6}{c}{ Regresi Linier } \\
\hline $\mathbf{r}_{\text {hitung }}$ & $\mathbf{r}_{\text {tabel }}$ & $\mathbf{R}_{\mathbf{x y}}^{2}$ & $\begin{array}{c}\text { Koefisien } \\
\boldsymbol{X}\end{array}$ & $\begin{array}{c}\text { Konstan } \\
\mathbf{t a}\end{array}$ \\
\hline 0.878 & 0.220 & 0.770 & 32.987 & 29.696 \\
\hline
\end{tabular}

Berdasarkan Tabel 4 terlihat bahwa pembelajaran menggunakan Project Based Learning berbasis media interaktif memiliki hubungan atau korelasi yang positif terhadap kemampuan komunikasi matematis mahasiswa. Hal ini sejalan dengan hasil penelitian (Musa, Mufti, Latiff, \& Amin, 2012) bahwa "project-based learning facilitates the growth of learners in comunication skills". Project-based learning has a medium to large positive effect on students' academic achievement compared with traditional instruction. In addition, the mean effect size was affected by subject area, school location, hours of instruction, and information technology support, but not by educational stage and small group size (Huan Chen \& Cih Yang, 2018).

Faktor yang membuat Project Based Learning dapat mempengaruhi kemampuan komunikasi matematis mahasiswa diantaranya adalah Project Based Learning yang diterapkan dapat membuat mahasiswa termotivasi dan aktif dalam menyelesaikan masalah persamaan garis singgung lingkaran melalui keterampilan mengelola beragam sumber secara kooperatif. Mahasiswa terlibat langsung dalam proses diskusi dengan teman maupun dosen tentang masalah persamaan garis singgung lingkaran yang diberikan, sehingga mahasiswa dapat mengevaluasi pendapat temannya untuk menarik kesimpulan. Pengalaman mahasiswa saat proses pembelajaran (merancang, investigasi, memecahkan masalah, dan membuat keputusan) membuat mereka semakin mantap dalam mempresentasikan hasil tugas proyek yang diberikan.

Hasil analisis didapatkan koefisien determinasi $r_{x y}^{2}$ sebesar 0.770 yang berarti Project Based Learning berbasis media interaktif dapat mempengaruhi kemampuan komunikasi matematis mahasiswa sebesar $77 \%$. Hal tersebut menunjukkan bahwa selain Project Based Learning berbasis media interaktif masih ada $23 \%$ dari faktor lain yang dapat mempengaruhi kemampuan komunikasi matematis mahasiswa. Berdasarkan beberapa hasil penelitian yang telah dilakukan menunjukkan bahwa beberapa faktor yang lain yang mempengaruhi kemampuan komunikasi matematis seseorang diantaranya adalah self efficacy, kepercayaan diri, kemampuan penalaran matematis, dan. Hal tersebut diperkuat oleh (Hendriana \& Kadarisma, 2019) yang menyatakan bahwa self efficacy memiliki pengaruh yang signifikan terhadap kemampuan komunikasi matematis. Untuk menunjang terciptanya kemampuan komunikasi matematis yang baik, rasa percaya diri penting untuk dimiliki oleh seseorang (Putri, Dwijayanto, \& Sugiman, 2017). Menurut hasil penelitian (Inayah, 2016) menunjukkan ada perbedaan kemampuan komunikasi matematis berdasarkan kemampuan penalaran matematis.

Selanjutnya besar bilangan konstanta sebesar 29.696 dan besar koefisien Project Based Learning berbasis media interaktif $(X)$ sebesar 32.987, maka persamaan regresi dapat dinyatakan sebagai berikut: $\hat{Y}=$ 
$32.987+29.696 X$. Persamaan tersebut menunjukkan bahwa apabila Project Based Learning berbasis media interaktif $(X)$ meningkat 1 poin maka kemampuan komunikasi matematis meningkat 29.696 poin.

Adanya pengaruh Project Based Learning terhadap kemampuan komunikasi matematis mahasiswa sejalan dengan hasil penelitian (Ning \& Kumalaretna, 2017) dalam hasil penelitiannya menyatakan bahwa PjBL efektif meningkatkan kemampuan komunikasi matematis siswa. Selain itu hasil penelitian (Ristanovic, 2016) menyatakan bahwa pembelajaran proyek mendorong perkembangan perilaku kolaboratif siswa. Hasil penelitian (Ngurah, Saputra, Joyoatmojo, \& Harini, 2018) juga menunjukkan bahwa PjBL meningkatkan aktifitas belajar siswa, termasuk kemampuan komunikasi matematis siswa.

\section{KESIMPULAN DAN SARAN}

Berdasarkan hasil dan pembahasan yang telah jelaskan dapat ditarik kesimpulan bahwa pembelajaran dengan model project based learning berbasis media interaktif memiliki korelasi yang positif terhadap kemampuan komunikasi matematis mahasiswa sebesar $77 \%$. Hal tersebut menunjukkan bahwa selain project based learning berbasis media interaktif masih ada $23 \%$ dari faktor lain yang dapat mempengaruhi kemampuan komunikasi matematis mahasiswa.

Hasil penelitian ini hendaknya dapat menjadi pertimbangan mengenai pentingnya penggunaan model pembelajaran dalam menyampaikan materi agar dapat diterima mahasiswa lebih mudah, sehingga dapat meningkatkan kemampuan komunikasi matematis mahasiswa.

\section{DAFTAR PUSTAKA}

Abdul, R., Mohammad, Y., \& Kashefi, H. (2012). Developing mathematical communication skills of engineering students. Procedia- Social and Behavioral Science, 46, 5541-5547. https://doi.org/10.1016/j.sbspro.20 $\underline{12.06 .472}$

Amamou, S., \& Cheniti-belcadhi, L. (2018). Tutoring In Project-Based Learning. Procedia Computer Science, 126, 176-185. https://doi.org/10.1016/j.procs.20 18.07 .221

Arifin, Z. (2017). Kriteria Instrumen dalam Suatu Penelitian, 2(1), 2836.

Arikunto, S. (2015). Dasar-dasar Evaluasi Pendidikan. Jakarta: Bumi Aksara.

Budiyono. (2016). Statistik Untuk Penelitian. In Suyono (Ed.) (2nd ed.). Surakarta: UNS Press.

Chen, C., \& Yang, Y. (2019). Revisiting the e ff ects of project-based learning on students 'academic achievement: A meta-analysis investigating moderators. Educational Research Review, 26(December 2017), 71-81. https://doi.org/10.1016/j.edurev.2 018.11 .001

Fahrullisa, R., Putra, F. G., \& Supriadi, N. (2018). Pengaruh Model Pembelajaran Kooperatif Tipe Think Pair Share ( TPS ) berbantuan Pendekatan Investigasi terhadap Kemampuan Komunikasi Matematis. Numerical, 2(2), 145-152.

Garnjost, P., \& Lawter, L. (2019). The International Journal of Undergraduates' satisfaction and perceptions of learning outcomes across teacher- and learnerfocused pedagogies. The 
DOI: https://doi.org/10.24127/ajpm.v8i3.2203

International Journal of Management Education, 17(2), 267-275.

https://doi.org/10.1016/j.ijme.201 9.03.004

Ngurah, I. G., Saputra, H., Joyoatmojo, S., Harini, H. (2018). The Implementation of Project-Based Learning Model and Audio Media Visual Can Increase Students' Activities. International Journal of Multicultural and Multireligious Understanding. 166-174.

http://dx.doi.org/10.18415/ijmmu. v5i4.224

Hamzah, A. (2014). Evaluasi Pembelajaran Matematika. Jakarta: Rajawali Pers.

Hendriana, H., \& Kadarisma, G. (2019). Self-Efficacy dan Kemampuan Komunikasi Matematis Siswa SMP, 3(1), 153-164.

Huan Chen, C., \& Cih Yang, Y. (2018). Revisiting the effects of projectbased learning on students' academic achievement: A metaanalysis investigating moderators. Educational Research Review. Elsevier Ltd. https://doi.org/10.1016/j.edurev.2 018.11 .001

Imaniar Ramadhan, E. D. M. (2018). Analisis Kemampuan Komunikasi Matematis Siswa SMP dalam Menyelesaikan Soal Lingkaran. Journal of Medives.

Inayah, N. (2016). Pengaruh kemampuan penalaran matematis dan gaya kognitif terhadap kemampuan komunikasi dan koneksi pada materi statistika siswa sma, 2(5), 74-80.

Lasauskiene, J., \& Rauduvaite, A. (2015). Project-Based Learning at University: Teaching Experiences of Lecturers. Procedia - Social and Behavioral Sciences, 197(February), 788-792. https://doi.org/10.1016/j.sbspro.20 15.07 .182

Lestari, K. E., \& Yudhanegara, M. R. (2015). Penelitian Pendidikan Matematika. Bandung: PT Refika Aditama.

Lisa, Y., Hayati, S., Djatmika, E. T., \& Rahman, A. (2018). Pengaruh Model Pembelajaran Tutor Sebaya terhadap Kemampuan Komunikasi Matematis Siswa Sekolah Dasar. Jurnal Pendidikan, 3(8), 2010-2012.

Mulyadi, E. (2015). Penerapan Moden Project Based Learning untuk Meningkatkan Kinerja dan Prestasi Belajar Fisika Siswa SMK. Jurnal Pendidikan Dan Teknologi Kejuruan, 22(4), 385395.

Musa, F., Mufti, N., Latiff, R. A., \& Amin, M. M. (2012). Projectbased learning $(\mathrm{PjBL})$ : inculcating soft skills in 21 century workplace, 59(2006), 565-583. https://doi.org/10.1016/j.sbspro.20 12.09 .315

Ning, W., Kumalarenta, D. (2017). Kemampuan Komunikasi Matematis Ditinjau dari Karakter Kolaborasi dalam Pembelajaran Project Based Learning (PjBL). Unnes Journal of Mathematics Education Research. 6 (2), 195205.

Nuryadi, \& Rahmawati, P. (2018). Persepsi siswa tentang penerapan model pembelajaran berbasis proyek ditinjau dari kreativitas dan hasil belajar siswa. Mercumatika, 3(1), 53-62.

Putra, F. G. (2016). Pengaruh Model Pembelajaran Reflektif dengan Pendekatan Matematika Realistik 
DOI: https://doi.org/10.24127/ajpm.v8i3.2203

Bernuansa Keislaman terhadap Kemampuan Komunikasi Matematis. Al-Jabar, 7(2), 203210.

Putra, F. G., Widyawati, S., Asyhari, A., \& Putra, R. W. Y. (2018). The Implementation of Advance Organizer Model on Mathematical Communication Skills in terms of Learning Motivation. Tadris, 3(1), 41

Putri, L., Dwijayanto, \& Sugiman. (2017). Analysis of Mathematical Communication Skills and Confidence of 10 th Grader of SMK in Geometry Material Viewed from Cognitive Style. UJME, 6(1), 97-107. https://doi.org/10.15294/ujme.v6i $\underline{1.1264}$

Rahman, R. A., Yusof, Y. M., Kashefi, H., Baharun, S. (2012). Developing Mathematical Communication Skills of Engineering Students. Procedia Social and Behavioral Sciences, 46 , 5541-5547. https://doi.org/10.1016/j.sbspro. 20 12.06 .472

Ristanovic, Dusan. (2016). The role of the project-based learning model in science and social studies teaching in the development of collaborative behavior in students. Nastava $i$ vaspitanje. 65 (3). 629646. DOI 10.5937/nasvas $1603629 \mathrm{R}$

Sugiyono, S. (2018). Metode Penelitian Kuantitatif. Bandung: Alfabeta.

Swadaya, U., \& Jati, G. (2008). Kemampuan Penalaran dan Komunikasi Matematis: Apa, Mengapa, dan Bagaimana Ditingkatkan pada Mahasiswa. Euclid, 1(1), 33-46.
Tayeb, T., Sulhaerah, A., \& Ali, M. (2015). Pengaruh Prestasi Belajar Micro Teaching Terhadap Praktik Pengalaman Lapangan Angkatan 2010/2011 Mahasiswa Jurusan Pendidikan Matematika Fakultas Tarbiyah Dan Keguruan Uin Alauddin Makassar. MaPan Jurnal Matematika Dan Pembelajaran, 3(1), 73-84. 